\title{
Phenotypic changes in pseudomonas aeruginosa induced by sub-inhibitory exposure to chlorohexidine
}

\begin{tabular}{lll}
\hline Safaa Toma Aka * & Sayran Hamad Haji * \\
\hline & Abstract &
\end{tabular}

Background and objective: Many bacterial isolates show an increased antimicrobial resistance due to biofilm production. Repeated exposure to sub lethal concentrations of antimicrobial agents certainly contributes to the resistance as compared to planktonic bacteria. The aim of this study was to test whether the bacterial phenotypes of $P$. aeruginosa can be changed during exposures to the concentrations at sub lethal doses of chlorhexidine.

Methods: Sheep blood agar plates were used for evaluation of haemolysin assay for isolates of $P$. aeroginusa. A 96-flat bottom well microtiter plates were used for determination of MIC of antibiotic and biofilm formation.

Results: All tested isolates were able to lyse RBCs after exposure to sub-MIC of chlorhexidine. Effectiveness of sub-lethal doses of chlorhexidine on biofilm formations varied depending on the contact time. In general, long contact time exhibited increasing biofilm than short time. No significant difference in biofilm was detected among contact times: day I, day II and day III ( $P=0.132, P=0.139$ and $P=0.125$, respectively). The most effective sub-MIC of $\mathrm{CHX}$ was against azithromycin, since the resistance increased significantly $(P=0.008)$.

Conclusion: Surviving P. aeruginosa to low concentration of chlorhexidine can exhibit stronger biofilm and increased resistance to antibiotics.

Keywords: Biofilm, Chlorhexidine, Antibiotics, P. aeruginosa.

\section{Introduction}

Antiseptics and disinfectants have been used in clinical and domestic applications for over half a century. Currently, the use of these products are in question, since persistent exposure to such agents can have harmful effects on human health and can select for less susceptible strains towards biocides and antibiotics. ${ }^{1}$ Chlorhexidine $(\mathrm{CHX})$ as a cationic antimicrobial agent of quaternary ammonium compounds (QACs) has different behavior, which differs from other cationic biocides in that they interact only superficially with the lipid bilayer altering fluidity through cation displacement and head group bridging. ${ }^{2}$ Many bacterial isolates of Pseudomonas aeruginosa show an increased antimicrobial resistance due to producing biofilm, which is defined as a surface-attached (sessile) community of microorganisms growing embedded in a self-produced matrix of extracellular polymeric substances (EPS). ${ }^{3}$ The basic modes of action of bacterial resistance to antimicrobials are generally well documented, although data continue to accumulate about the nature and importance of efflux systems. ${ }^{4}$ Biofilm is commonly associated with major clinical consequence of different infectious disease correlates with the problems of therapeutic killing of attached cells. ${ }^{5}$ The mechanisms by which Pseudomonas aeruginosa resist killing by antimicrobial and biocides are still poorly defined, even though repeated exposure to sub lethal concentrations of antimicrobial agents certainly contributes to the resistance as compared to planktonic. ${ }^{6}$ Decontamination and disinfection is an important and often challenging task, due

* Department of pharmacogonsy, College of Pharmacy, Hawler Medical University, Erbil, Iraq. 
http://dx.doi.org/10.15218/zjms.2014.0044

to increasing number of nosocomial infections, which was the motive to set up a sanitation program that indicates the appropriate chemical agents were chosen for application in the most effective way. Minimal inhibitory concentration (MIC) was submitted to study and compare the behavior of selected microorganisms. ${ }^{7}$ The term sub-MIC will be used to refers to concentrations of antimicrobial that do not affect the growth of the organism being tested. ${ }^{8,9} \mathrm{~A}$ wide variety of active biocides have been used for hundreds of years for antisepsis, disinfection, but less is known about the mode of action of these active agents than about antibiotics. In general, biocides have a broader spectrum activity than antibiotics, and, while antibiotics tend to have specific intracellular targets, biocides may have multiple targets. In fact, the widespread use of antiseptic and disinfectant has prompted some assumption on the development of microbial resistance, in particular cross-resistance to antibiotics. ${ }^{10}$ On the other hand, various studies have shown that sub-MIC of antimicrobial may induce biofilm formation. This process may have clinical relevance, since bacteria are continuously exposed to sub-MIC during low concentrations of disinfectants ${ }^{.9}$ This inappropriate procedure has become difficult to control bacterial biofim through cleaning and disinfection. ${ }^{11}$ The aim of this study was to test whether the bacterial phenotypes such as biofilm formation, haemolysis and antibiotic resistance of $P$. aeruginosa isolated from patients can be changed during exposures to the concentrations at sub lethal doses of chlorhexidine, a commonly used hospital disinfectant.

\section{Methods}

\section{Bacterial isolates}

Eight clinical isolates of Pseudomonas aeruginosa were collected from patients suffering from otitis media at Rizgary Teaching Hospital in Erbil, Kurdistan region, Iraq.

\section{Antimicrobial agent and biocicides}

The susceptibility of $P$. aeruginosa isolates to the following antimicrobial agents and biocides were tested: ceftriaxone at a concentration of $1000 \mathrm{mg} / \mathrm{ml}$, ampiclox at $500 \mathrm{mg} / \mathrm{ml}$, azithromycin at $250 \mathrm{mg} / \mathrm{ml}$, and ciprofloxacin at $500 \mathrm{mg} / \mathrm{ml}$. All antibiotics were used as raw materials (Mepha/Switzerland). Biocide 4\% (w/v) chlorhexidine ( $\mathrm{CHX}$ ) (Al-Rhma pharmaceutical co.) as laboratory standard solution. All solutions were filtered sterilized using a $0.2 \mu \mathrm{m}$ cellulose syringe filter (Jet-biofilm, China).

\section{Inoculation preparation}

The stock cultures were maintained in trypticase soy agar (TSA, Difco) at $4{ }^{\circ} \mathrm{C}$. Weekly transferences were developed with the purpose to maintain the viability of microorganisms. $^{12}$

Determination of sub-minimum inhibitory concentrations (sub-MICs) of CHX

The sub-MIC values of $\mathrm{CHX}$ against $\mathrm{P}$. aeruginosa were tested. ${ }^{1,5}$ Standard MICs were determined by macrodilution using a set of $10 \mathrm{ml}$ capacity tubes. Briefly, $50 \mu \mathrm{L}$ of adjusted bacterial suspension containing $1 \times 10^{8} \mathrm{cfu} / \mathrm{ml}$ adjusted with MacFarlad 0.5 (biomerieux) in TSB broth were added to $5 \mathrm{ml}$ of serial twofold dilutions of the $\mathrm{CHX}$. The tubes were incubated for $24 \mathrm{~h}$ at $37^{\circ} \mathrm{C}$ and observed for turbidity. The MIC was defined as the lowest concentration of $\mathrm{CHX}$ needed to inhibit visible bacterial growth compared to the control culture, while sub-MIC are those concentrations below the MIC, that inhibit normal cellular functions without causing death. ${ }^{13}$ The bacterial growth were grown in tube treated with sub -MIC of CHX were kept at contact-time (control, day I, day II, day III and week I), subsequently. The effect of $\mathrm{CHX}$ at different contact-time was evaluated against bacterial isolates. Tests were performed in triplicate with negative and positive controls.

Influence of sub-MICs of CHX on haemolysin production

The method used for evaluation of haemolysin assay for eight selected 
http://dx.doi.org/10.15218/zjms.2014.0044

producing-hemolysin bacterial isolates of $P$. aeroginusa. One loopful of bacterial growth was transferred from each sub-MIC tube of $\mathrm{CHX}$ at different contact-time onto sheep blood agar plate, then observed for their ability to lyse blood cells following incubation for $24 \mathrm{hrs}$ at $37^{\circ} \mathrm{C} .^{14}$ Bacteria that could completely lyse the blood cells forming a clearing zone around the colonies were called $\beta$-haemolytic, while partially break down the blood cells causing brown or green discoloration of the agar around the colony were called $\alpha$-haemolytic and bacteria that cannot lyse the blood cells were called $\mathrm{y}$-haemolytic.

Influence of sub-MICs of CHX on biofilm formation

Biofilm formation on polystyrene surface was conducted by growing bacterial isolates on 96-flat bottom well microtiter plates (Costar/USA). ${ }^{1} 200 \mu \mathrm{l}$ of nutrient broth were added to all 96 wells. Bacterial cells from different contact-time of sub-MIC of $\mathrm{CHX}$ tube were prepared. The turbidity of each bacterial suspension was adjusted with McFarland tube 0.5. All plates were inoculated with the bacterial suspension $\left(5 \mu \mathrm{l}\right.$ per well) and were incubated at $37^{\circ} \mathrm{C}$ for $24 \mathrm{hrs}$. After incubation, the plates were washed by PBS pH 7.2 for three times, then were exposed to air-dry, $200 \mu \mathrm{l}$ of $0.1 \%$ crystal violet was added to each well, the plates were incubated at room temperature for 30 minutes, then washed off using distilled water and kept for air dry. The bound bacteria were quantified by addition of ethanol $70 \%$ and measurement of the dissolved crystal violet at absorbance of $630 \mathrm{~nm}$ using 96-flat wells microtiter plate of the ELISA reader ELX800 (Biotek / USA). Each result represents the mean of at least three separate experiments.

Influence of sub-MICs of $\mathrm{CHX}$ on antibiotic resistance

Standard broth microdilution 96- flat well plate and MIC-value was used for the test. ${ }^{6}$ Two fold serial dilution ( $1 \mathrm{up}$ to $512 \mu \mathrm{g} / \mathrm{ml}$ ) of four types of selected antibiotics were prepared. The concentrations of antibiotics allocated on the wells $(200 \mu \mathrm{l}$ per well) starting from well number one up to well number ten, while well 11 and 12 were kept as a control negative and positive respectively. All wells except control negative were inoculated with $5 \mu \mathrm{L}$ of a bacterial suspension that was transferred from tubes at different contact time. The plate was incubated for $24 \mathrm{hrs}$ at $37^{\circ} \mathrm{C}$. The MIC was taken as the lowest concentration of the antibiotic that inhibits the bacterial growth. This procedure took place for a week contact time (day I, day II, day III and week I). Each result represents the mean of at least three separate experiments.

\section{Statistical analysis of data}

The paired-sample t-test was performed for statistical data analysis to determine whether there was a significant difference between MIC-value and biofilm formation at different time contacts. A P $\leq 0.05$ was considered statistically significant.

\section{Results}

\section{Hemolysin production}

All tested isolates of $P$. aeruginosa kept their ability to $\beta$-hemolysis after exposure to sub-MIC doses of $\mathrm{CHX}$ for different contact times from one day up to seven days.

\section{Biofilm formation}

Effectiveness of sub-lethal doses of $\mathrm{CHX}$ on biofilm formations varied depending on the contact time. In general, long contact time exhibited increasing biofilm than short time. Paired samples statistics showed no significant difference in biofilm among contact time: day I, day II and day III $(P=0.132, P=0.139$ and $P=0.125$, respectively). The results changed significantly $(P<0.001)$ following one week, since this time showed stronger biofilm than three days (Figure 1). 


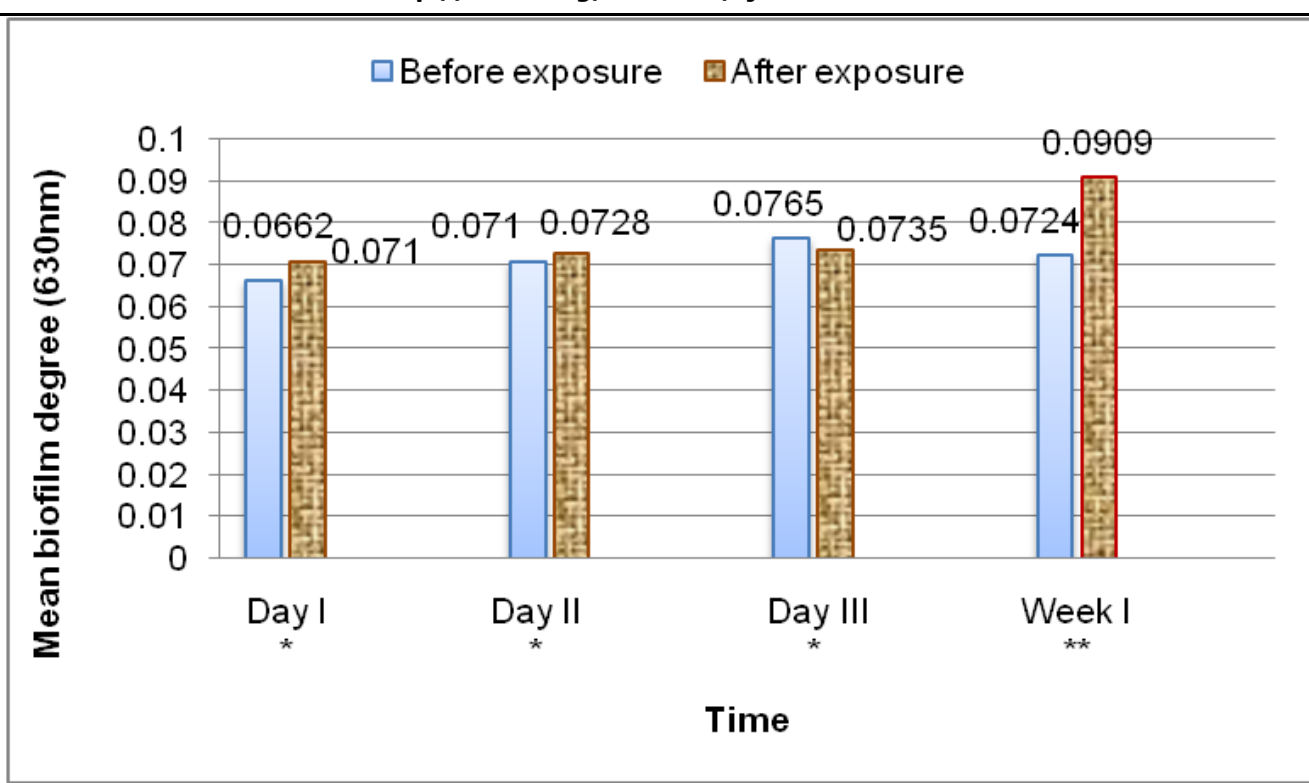

The mean difference is non-significant at $\left(^{*}\right) \mathrm{P}>0.1$ and significant at $\left(^{* *}\right) \mathrm{P}<0.001$

Figure 1: The degree of biofilm formation by $\mathrm{P}$. aeruginosa following exposure to sub-MIC of $\mathrm{CHX}$ at different contact time.

\section{Antibiotic resistance}

The efficacy of $\mathrm{CHX}$ showed no significant difference on bacterial isolates against ceftriaxone at contact time of day I and day II $(P=0.174$ and $P=0.567$, respectively $)$.
Bacterial isolates could increase their resistance to the same types of antibiotics at day III and week I, as raised the MIC values $(P=0.02$ and $P=0.014$, respectively) as shown in Table 1.

Table 1: The MIC determination of ceftriaxone against eight bacterial isolates of $\mathrm{P}$. aeruginosa at different contact time of $\mathrm{CHX}$.

\begin{tabular}{|c|c|c|c|c|c|c|c|c|}
\hline $\begin{array}{l}\text { P. aerugiousa } \\
\text { Isolates }\end{array}$ & $\begin{array}{l}\text { Day I } \\
\text { Before }\end{array}$ & After & $\begin{array}{l}\text { Day II } \\
\text { Before }\end{array}$ & After & $\begin{array}{l}\text { Day III } \\
\text { Before }\end{array}$ & After & $\begin{array}{l}\text { Week I } \\
\text { Before }\end{array}$ & After \\
\hline P.1 & 8 & 128 & 512 & 256 & 64 & 512 & 256 & 256 \\
\hline P.2 & 32 & 128 & 256 & 256 & 64 & 256 & 256 & 512 \\
\hline P. 3 & 32 & 32 & 32 & 64 & 32 & 64 & 32 & 128 \\
\hline P.4 & 64 & 64 & 64 & 128 & 64 & 128 & 64 & 256 \\
\hline P. 5 & 128 & 128 & 128 & 128 & 128 & 256 & 128 & 256 \\
\hline P.6 & 128 & 128 & 128 & 256 & 128 & 128 & 128 & 512 \\
\hline P.7 & 64 & 64 & 64 & 256 & 128 & 512 & 512 & 512 \\
\hline P.8 & 128 & 128 & 64 & 128 & 128 & 256 & 128 & 256 \\
\hline Mean $\pm S D$ & $\begin{array}{l}73 \pm \\
49.02\end{array}$ & $\begin{array}{l}100 \pm \\
39.88\end{array}$ & $\begin{array}{l}156 \pm \\
159.94\end{array}$ & $\begin{array}{l}184 \pm \\
79.77\end{array}$ & $\begin{array}{l}92 \pm \\
39.88\end{array}$ & $\begin{array}{l}264 \pm \\
169.11\end{array}$ & $\begin{array}{l}188 \pm \\
153.40\end{array}$ & $\begin{array}{l}336 \pm \\
152.03\end{array}$ \\
\hline$p$ value & \multicolumn{2}{|c|}{0.174} & \multicolumn{2}{|c|}{0.567} & \multicolumn{2}{|c|}{0.02} & \multicolumn{2}{|c|}{0.014} \\
\hline
\end{tabular}


http://dx.doi.org/10.15218/zjms.2014.0044

The susceptibility of isolates to ampiclox is presented in Table 2. The results showed various effects as the bacterial isolates started with no significantly resistance at day I and day II $(P=0.059$ and $P=0.0640$, respectively), then at day III could adapt the conditions $(P=0.424)$. At week $\mathrm{I}$,
The isolates showed significant resistance through raising the MIC-value $(P=0.011)$ in comparison to control. In contrast to above-mentioned results, the $\mathrm{CHX}$ could not change the sensitivity of bacterial isolates against ciprofloxacin at all contact times (Table 3).

Table 2: The MIC determination of ampiclox against eight bacterial isolates of $\mathrm{P}$. aeruginosa at different contact time of $\mathrm{CHX}$.

\begin{tabular}{|c|c|c|c|c|c|c|c|c|}
\hline \multirow{2}{*}{$\begin{array}{l}\text { P. aerugiousa } \\
\text { Isolates }\end{array}$} & \multicolumn{2}{|l|}{ Day I } & \multicolumn{2}{|l|}{ Day II } & \multicolumn{2}{|l|}{ Day III } & \multicolumn{2}{|l|}{ Week I } \\
\hline & Before & After & Before & After & Before & After & Before & After \\
\hline P.1 & 16 & 256 & 1024 & 1024 & 1024 & 512 & 512 & 512 \\
\hline P. 2 & 32 & 256 & 64 & 512 & 128 & 512 & 128 & 1024 \\
\hline P.3 & 64 & 64 & 64 & 64 & 64 & 128 & 64 & 256 \\
\hline P.4 & 64 & 128 & 64 & 256 & 256 & 512 & 256 & 512 \\
\hline P.5 & 64 & 64 & 128 & 256 & 128 & 256 & 256 & 512 \\
\hline P.6 & 128 & 256 & 128 & 256 & 256 & 256 & 256 & 512 \\
\hline P.7 & 128 & 128 & 128 & 256 & 128 & 256 & 256 & 512 \\
\hline P.8 & 64 & 64 & 128 & 128 & 64 & 256 & 128 & 512 \\
\hline Mean \pm SD & $\begin{array}{l}70 \pm \\
40.05\end{array}$ & $\begin{array}{l}152 \pm \\
90.10\end{array}$ & $\begin{array}{l}216 \pm \\
328.01\end{array}$ & $\begin{array}{l}344 \pm \\
303.93\end{array}$ & $\begin{array}{l}256 \pm \\
319.08\end{array}$ & $\begin{array}{l}336 \pm \\
152.03\end{array}$ & $\begin{array}{l}232 \pm \\
136.5\end{array}$ & $\begin{array}{l}544 \pm \\
213.6\end{array}$ \\
\hline$p$ value & \multicolumn{2}{|c|}{0.059} & \multicolumn{2}{|c|}{0.046} & \multicolumn{2}{|c|}{0.424} & \multicolumn{2}{|c|}{0.011} \\
\hline
\end{tabular}

Table 3: The MIC determination of ciprofloxacin against eight bacterial isolates of $\mathrm{P}$. aeruginosa at different contact times of $\mathrm{CHX}$.

\begin{tabular}{|c|c|c|c|c|c|c|c|c|}
\hline $\begin{array}{l}P \text {. aerugiousa } \\
\text { Isolates }\end{array}$ & $\begin{array}{l}\text { Day I } \\
\text { Before }\end{array}$ & After & $\begin{array}{l}\text { Day II } \\
\text { Before }\end{array}$ & After & $\begin{array}{l}\text { Day III } \\
\text { Before }\end{array}$ & After & $\begin{array}{l}\text { Week I } \\
\text { Before }\end{array}$ & After \\
\hline P.1 & 2 & 2 & 8 & 8 & 2 & 4 & 128 & 128 \\
\hline P.2 & 2 & 4 & 4 & 8 & 4 & 8 & 4 & 16 \\
\hline P. 3 & 2 & 2 & 2 & 2 & 2 & 2 & 2 & 4 \\
\hline P.4 & 2 & 2 & 2 & 2 & 2 & 2 & 2 & 8 \\
\hline P. 5 & 2 & 2 & 2 & 2 & 2 & 2 & 2 & 2 \\
\hline P. 6 & 2 & 2 & 2 & 2 & 2 & 2 & 2 & 4 \\
\hline P.7 & 2 & 2 & 2 & 2 & 2 & 2 & 2 & 2 \\
\hline P.8 & 2 & 2 & 2 & 2 & 2 & 2 & 2 & 2 \\
\hline Mean \pm SD & $2 \pm 0.00$ & $2.25 \pm 0.7$ & $3 \pm 2.1$ & $3.5 \pm 2.7$ & $2.25 \pm 0.7$ & $3 \pm 2.1$ & $18 \pm 44.4$ & $20.7 \pm 43.5$ \\
\hline$p$ value & \multicolumn{2}{|l|}{0.351} & \multicolumn{2}{|c|}{0.351} & \multicolumn{2}{|c|}{0.197} & \multicolumn{2}{|c|}{0.111} \\
\hline
\end{tabular}


http://dx.doi.org/10.15218/zjms.2014.0044

Table 4: The MIC determination of azithromycin against eight bacterial isolates of $\mathrm{P}$. aeruginosa at different contact times of $\mathrm{CHX}$.

\begin{tabular}{|c|c|c|c|c|c|c|c|c|}
\hline $\begin{array}{l}\text { P. aerugiousa } \\
\text { Isolates }\end{array}$ & $\begin{array}{l}\text { Day I } \\
\text { Before }\end{array}$ & After & $\begin{array}{l}\text { Day II } \\
\text { Before }\end{array}$ & After & $\begin{array}{l}\text { Day III } \\
\text { Before }\end{array}$ & After & $\begin{array}{l}\text { Week I } \\
\text { Before }\end{array}$ & After \\
\hline P.1 & 8 & 32 & 16 & 16 & 8 & 16 & 32 & 128 \\
\hline P.2 & 64 & 64 & 64 & 64 & 64 & 64 & 64 & 128 \\
\hline P.3 & 256 & 256 & 512 & 512 & 512 & 512 & 512 & 1024 \\
\hline P.4 & 256 & 256 & 256 & 512 & 256 & 512 & 512 & 1024 \\
\hline P. 5 & 128 & 128 & 128 & 256 & 128 & 256 & 128 & 256 \\
\hline P. 6 & 256 & 256 & 256 & 256 & 256 & 512 & 256 & 512 \\
\hline P.7 & 128 & 128 & 128 & 256 & 128 & 256 & 256 & 1024 \\
\hline P. 8 & 256 & 256 & 128 & 256 & 256 & 512 & 256 & 512 \\
\hline Mean \pm SD & $\begin{array}{l}169 \pm \\
100\end{array}$ & $\begin{array}{l}172 \pm \\
95.1\end{array}$ & $\begin{array}{l}186 \pm \\
155.8\end{array}$ & $\begin{array}{l}266 \pm \\
179.1\end{array}$ & $\begin{array}{l}201 \pm \\
156.9\end{array}$ & $\begin{array}{l}330 \pm \\
211.3\end{array}$ & $\begin{array}{l}252 \pm \\
182.9\end{array}$ & $\begin{array}{l}576 \pm \\
398.9\end{array}$ \\
\hline p value & \multicolumn{2}{|c|}{0.351} & \multicolumn{2}{|c|}{0.049} & \multicolumn{2}{|c|}{0.017} & \multicolumn{2}{|c|}{0.008} \\
\hline
\end{tabular}

The most effectiveness of $\mathrm{CHX}$ at sub-MIC concentrations on tested bacteria was against azithromycin. The MIC-value increased significantly starting from day II, day III and week I $(P=0.049, P=0.017$ and $P=0.008$, respectively) as shown in Table 4.

\section{Discussion}

This study was designed to assess the effectiveness of $\mathrm{CHX}$ at their sub lethal concentrations on some phenotypic changes of $P$. aeruginosa. Three virulence factors were included; hemolysin production, biofilm formation and bacterial resistance to antibiotic. Hemolysin is recognized as potential virulence factor produced by most pathogenic bacteria, which can put a human's health at risk. Hemolysin phenotype was observed with the method of sheep blood agar. The results demonstrated no changes of hemolysin production by the eight isolates after they were exposed to $\mathrm{CHX}$. In fact, hemolysin production is regulated by gene expression to get iron for nutrition. Research has revealed that gene expression of hemolysin is repressed in the presence of iron. ${ }^{16}$ This ensures that hemolysin is produced only when needed. Thus, the mechanism of gen inhibition might be caused unchanged hemolysin phenotype following exposures to $\mathrm{CHX}$ in contact time. In recent works, considerable progress has been made in understanding the response of bacterial isolates to antiseptics. For example, the nature and composition of outer layer of $P$. aeruginosa may act as a permeability barrier, in which there may be reduced uptake as described by Russell. ${ }^{17}$ It appears that the efficacy of $\mathrm{CHX}$ is associated with changes in the cell envelope. This observation is reinforced by finding presented by Prince et $\mathrm{al}^{18}$ who reported that resistant strains to $\mathrm{CHX}$ did not show altered biochemical properties of changed virulence. Further study reviewed by McDonnell and Russell ${ }^{19}$ could support these finding, who revealed that only the high concentration $\mathrm{CHX}$ can inhibit only the membrane-bound, which suggested that the enzymes is not a primary target for $\mathrm{CHX}$ action. The second aim of the study was to evaluate the efficacy of $\mathrm{CHX}$ on 
biofilm formation at sub lethal concentrations in different contact times. The goal of this line was to demonstrate the bacterial tolerance, which permit microorganisms to survive in the presence of an active biocide. Many reports of this style were reviewed in hospital environments, which include inadequate cleaning, incorrect products use and on effective infection control practice. In fact, microorganisms can adapt to variety chemical conditions and therefore not surprising that resistance to extensively used disinfectants and antiseptics has been reported. ${ }^{19}$ The most significant mechanism is clearly intrinsic, in particular the ability to adaptation that develops protective biofilm of Pseudomonas. In these cases "resistance" may be incorrectly used and "tolerance" may be more correct as reviewed by McDonnell and Russell. ${ }^{19}$ This study showed no significant difference in biofilm formation after three days of exposure to sub-MIC doses, but could change significantly after one week. This change might have a relation to adaptation or bacterial tolerance as described above. Several instances in hospitals are known of contamination of antiseptic and disinfectant solutions by bacteria can support our observation. For example, studies demonstrated that prolonged survival of bacterial isolates in sub-lethal dose $(2 \% \mathrm{CHX})$ was attributed to the embedding these microorganisms in a thick matrix that adhered to the walls of a container. ${ }^{20,21}$ One certain conclusion about what mentioned above, the interaction of bacteria with surface is usually reversible and eventually irreversible. Irreversible adhesion is initiated by binding of bacteria to the surface through exopolysaccharide glycocalyx matrix. New cells then arise by cell division are bound within glycocalyx polymers. ${ }^{19}$ The last field of the experiment included the efficacy of $\mathrm{CHX}$ at low doses on bacterial resistance against antibiotics, through, determination of MIC-value following exposures. Step-wise exposure of $P$. aeruginosa isolates to gradually increasing contact time of $\mathrm{CHX}$ resulted in having the organism exhibiting increased MIC-value to antibiotics. Ciprofloxacin was the only antibiotic that $P$. aeruginosa isolates showed no less sensitive to $\mathrm{CHX}$ than the remained types of antibiotics, which exhibited raised MIC-value particularly after day III and week I. In fact, antibiotic resistance by bacterial isolates may be the result of phenotypic adaptation and survivals in environment where growth conditions are limiting or the cells are under stress. ${ }^{22}$ However, sub lethal exposure to $\mathrm{CHX}$ can provoke antibiotic resistance through expression of efflux pump, which plays an important role in multidrug resistance in $P$. aeruginosa in hospitals where $\mathrm{CHX}$ are used frequently. ${ }^{22}$ The present study showed bacterial biofilm that induced by low concentrations of $\mathrm{CHX}$, can also adopt a part of resistance to antibiotics. The objective of the work presented in the last field was to evaluate the significance of penetration limitation as a mechanism of biofilm resistance to different groups of antibiotics such as $\beta$-lactams, azithromycin and ciprofloxacin. $P$. aeruginosa isolates showed no changes in sensitivity to ciprofloxacin before and after exposures to $\mathrm{CHX}$. In contrast to the situations with ciprofloxacin, the sensitivity decreased against $\beta$-lactams and azithromycin through raised MIC-value. Poor penetration contributed to biofilm resistance to $\beta$-lactams but not to ciprofloxacin as described by Andrel et $\mathrm{al}^{23}$ who hypothesized that the failure of $\beta$-lactams penetrate biofilms was due to its deactivation in the surface layers of biofilm faster than could diffuse in. Azithromycin is known to inhibit biofilm growth of $P$. aeruginosa, but the exact mechanism that mediates the azithromycin anti-Pseudomonas activity remains uncertain. Recent study proposed a two-step process in which azithromycin first permeabilizes the outer membrane and then causes cell death by inhibiting protein synthesis and/or ribosome assembly. ${ }^{24}$ The present work showed that P. aeruginosa isolates revealed much greatest resistance to 
http://dx.doi.org/10.15218/zjms.2014.0044

azithromycin through increased MIC-value. In fact, the above-mentioned mechanism of low concentration of $\mathrm{CHX}$ act on membrane-bound could change the permeability. This process might cause a barrier to prevent azithromycin penetration to reach its primary internal target. However, in some situations antibiotic resistance can be achieved without any genetic alteration; this is called phenotypic resistance, which is associated to specific processes such as growth in biofilm. ${ }^{25}$

\section{Conclusion}

Surviving $P$. aeruginosa exposed to $\mathrm{CHX}$ at low concentrations exhibited various phenotypic changes in pathogenicity. The isolates can build up stronger biofilm and increased resistance to antibiotics by MIC value. Therefore, incorrect use or dilution of disinfectants could lead to microbial population that is more resistance to antibacterial agents.

\section{Conflicts of interest}

The authors report no conflicts of interest.

\section{References}

1. Houari A, Di Martino P. Effect of chlorhexidine and benzalkonium chloride on bacterial biofilm formation. Lett Appl Microbiol 2007; 45:652-6.

2. Chawner JA, Gilbert P. A comparative study of the bactericidal and growth inhibitory activities of the bisbiguanides alexidine and chlorhexidine. J Appl Bacteriol 1989; 66:243-52.

3. Pantanella F. Valenti P. Natalizi T. Passeri D. Analytical technique to study microbial biofilm on a biotic surface: pros and cons of main techniques currently in use. Ann Ig 2013; 25(1):31-42.

4. Russell AD. Antibiotic and biocide resistance in bacteria: Introduction. J Appl Microbiol Symposium 2002; Supp 92:1S-3S.

5. Masadeh MM, Mhaidat NM, Alzoubi KH, Hussein El, Al-Trad El. In vitro determination of the antibiotic susceptibility of biofilm-forming Pseudomonas aeruginosa and Staphylococcus aureus: possible role of proteolytic activity and membrane lipopolysaccharide. Infect Drug Resist 2013; 6:27-32.

6. Braoudaki M, Hilton AC. Adaptative resistance to biocides in Salmonella enterica and Escherichia coli 0157 and cross resistance to antimicrobial agents. J Clin Microbiol 2004; 42(1):73-8.

7. Mazzola PG, Jozala AF, Novaes LC, Moriel P, Penna TC. Minimal inhibitory concentration (MIC) determination of disinfectant and/or sterilizing agents. Brazil J Pharm Sci 2009; 45(2):241-8.

8. Davis J, Spiegelman GB, Yim G. The world of sub-inhibitory antibiotic concentrations. Curr Opin Microbiol 2006; 9(5):445-53.

9. Kaplan JB. Antibiotic induced biofilm formation. Int J Artif Organs 2011; 34 (9):737-51.

10. Mdonnell G, Russell AD. Antiseptics and Disinfectants: Activity, Action, and Resistance. Clin Microbiol Rev 1999; 12 (1):147-79.

11. Augustin M. Ali-Vehmas T. Assessment of enzymatic cleaning agents and disinfectants against bacterial biofilms. Pharm Pharmaceut Sci 2004; 7(1): 55-64.

12. Fazlara A, Ekhtelat M. The Disinfectant Effects of Benzalkonium Chloride on Some Important Foodborne Pathogens. American-Eurasian J Agric Environ Sci 2012; 12(1):23-9.

13. Dynes JJ, Lawrence JR, Korber DR, Swerhone GD, Hitchcock AP. Morphlogical and biochemical changes in Pseudomonas florescens biofilms induced by sub-inhibitory Exposure to antimicrobial agents. Can J Microbiol 2009; 55:163-78.

14. Bisen PS, Debnath M, Prasad GB, Microbes concepts and applications. Newjersy: John Wiley and sons Inc; 2012.

15. Anton NN. Bacteriological study of discharging ear and evaluation of the effect of certain antibacterial agents against biofilm forming bacteria. MSc 
Thesis in Microbiology. Hawler Medical University, College of Medicine; 2013.

16. Griffiths BB, McClain O. The role of iron in the growth and hemolysin (streptolysin S) production in Streptococcus pyogenes. J Basic Microbiol 2007; 28(7):427-36.

17. Russell AD. Mechanisms of bacterial resistance to biocides. Int Biodeterior Biodegrad 1995; 36:247-65.

18. Prince HN, Nonmarker WS, Norgard RC, Prince DL. Drug resistance with topical antiseptics. J Pharm Sci 1978; 67:1629-31.

19. McDonnell G, Russell D. Antiseptics and disinfectants: Activity, Action and Resistance. Clin Microbiol Rev1999; 12 (1):147-227.

20. Hugo WB, Pallent IJ, Grant DJ, Denyer SP, Davis A. Factors contributing to the survival of strain of Pseudomonas sepcia in chlorhexidine solution. Lett Appl Microbiol 1986; 2:37-42.

21. Russell AD. Mechanism of bacterial resistance to non-antibiotics: food additive and pharmaceutical preservatives. J Appl Bacteriol 1990; 71:191-201.

22. Thomas L, Russell AD, Maillard JY. Antimicrobial activity of chlorhexidine diastate and benzalkonium chloride against Pseudomonas aeruginosa and its response to biocide residues. J Appl Microbiol 2005; 98:533-43.

23. Andrel JF, Franklin MJ, Stewart PS. Role of antibiotic penetration limitation in Klebsiella pneumoniae biofilm resistance to ampicillin and ciprofloxacin. Antimicrob Agents Chemother 2000; 44:1818-24.

24. Xavier M, Macia D, Mena A, Juan C, Perez J, Oliver A. Azithromycin in Pseudomonas aeruginosa Biofilms: Bactericidal Activity and Selection of nfxB Mutants. Antimicrob Agents Chemother 2009; 53(4):1552-60.

25. Corona F, Martinez J. Phenotypic resistance to antibiotic. Antibiotic 2013; 2(2):237-55. 